\title{
INDONESIAN HUMAN RIGHTS POLITIC IN A RESTORATIVE JUSTICE CONCEPT
}

\section{Irsyad Dhahri Samad}

Universitas Negeri Makassar

cha4400@yahoo.com

\section{Article History}

accepted 09/07/2018

approved 01/08/2018

published 17/09/2018

\section{Keywords}

Primary Stakeholder, Social Discipline concept, Masykur Abdul Kadir, Abilio Soares, Indonesian Communist Party-PKI, the Constitutional Court.

\begin{abstract}
Although restorative justice model has been discouraged internationally, Indonesia has not formally used it within the judicial system. Therefore, in a way to socialize the model, the author is analyzing the cogency of a restorative theory of Primary Stakeholder proposed by McCold using Social Discipline concept on Indonesian human rights cases: Masykur Abdul Kadir against the Terrorism Act, Abilio Soares against Human Rights Court Law, and former members of Indonesian Communist Party-PKI against the General Election Law. The cases were in line with past actions but were in conflict with constitutional human rights protection, so then decided by the Constitutional Court. It were found that the court had to accomplish the needs of legal and political interests within the same time in a way to protect human rights and social comments were matter as they were driving court decisions of the cases. By this, although Masykur and other Bali Bombs trials had attracted social attentions leading to a high social sentiment to punished perpetrators, his legally constitutional rights that also supported by public opinion alongside government political deed had challenged the application the restorative concept. This was also seen in cases of Soares and former members of Indonesian Communist Party.
\end{abstract}

Social, Humanities, and Education Studies (SHEs): Conference Series https://jurnal.uns.ac.id/shes 


\section{INTRODUCTION}

As the use of restorative justice model has been discouraged by several countries in the 1990's. $s_{-j}$ The approach to settle criminal cases focusing on the protection of victims by involving direct participations of perpetrators, victims and communities in the settlement process continually made (Braithwaite, 2002). Then, in 2000, the United Nations issued Basic Principles on the Use of Restorative Justice Programs in Criminal Matters contain a number of fundamental principles of restorative justice approach (Zulfa, 2011). In Indonesia, the concept has been underwritten in light cases involving children which enable to be settled outside the court. However, although this approach is academically appealing (Karp \& Breslin, 2001), the use and the application have not been tested formally in Indonesian judicial system. Therefore, it is essential to examine whether the well understood restorative justice concept can be used in the country especially in cases related to human rights.

To support the study, the author chooses a theory of Primary Stakeholder proposed by McCold (McCold, \& Wachtel, 2003) using structural interconnected concepts of Social Discipline Window, Stakeholder Roles, and Restorative Practices Typology. For a brief discussion, this article only analyzes the concept of Social Discipline Window making this article as the first past of three articles discussing the restorative justice concepts of the primary stakeholder theory. Discussion in this article is focusing on three Indonesian cases dealing with past-related events decided by the Indonesian Constitutional Court (the Court) in line with the protection of human rights enforcement. In the first part, the author explains briefly what and how the concept of Social Discipline Window used within cases of Masykur who was sentenced 15 years against the Terrorism Act (Mahkamah Konstitusi, 2003), Soares who was sentenced 3 years against Human Rights Court Law (Decision No. 065/PUU-II/2004) and former members of Indonesian Communist Party-PKI against the General Election Law (Decision No. 011-017/PUU-I/2003). Then, the discussion followed by how Indonesian society react to Constitutional Court's decisions on these cases and how the government and the Constitutional Court manage the cases as the Social Discipline concept.

\section{A. The case of Masykur Abdul Kadir against the Terrorism Act}

In September 2002, Masykur Abdul Kadir (Masykur) (Butt, 2008) got acquainted and helped Sutomo to find accommodation and rental vehicles. On November 21, 2002, shortly after the Kuta bombing of Bali, the police arrested Sutomo, later known as Imam Samudra, a Bali bomber who was sentenced to death (Guardian, 2003) and Masykur on charge of assisting Imam Samudra's plot. The court sentenced him 15 years in prison despite no apparent evidence linking him to the bombing. Therefore, Masykur proposed against the legitimacy of Law no. 16 (2003) on the Bali bombing opposed to the Article $28 \mathrm{I}(1)$ of the 1945 Constitution of the Republic of Indonesia as well as the Article 1 (1) of the Criminal Code on retrospective issue and the Principle of Legality. The Constitutional Court confirmed the unconstitutionality and annulled the Law No. 16 (2003) for the sake of human rights. However, the Minister of Justice and Human Rights and the Chief Justice of the Constitutional Court (almost at the same time) announced that the Court's decision was prospective.

\section{B. The case of Abilio Soares against Human Rights Court Law}

Based on the Law no. 26 (2000) on the Human Rights Court, Abilio Jose Osorio Soares (former Governor of East Timor) was sentenced 3 years in 2002 and convicted of murder and torture against civilians in East Timor on April-September 1999. However, since this law applies past event enhanced by the existence of Article 51 states '... law is 
effective on the date of stipulation', Soares proposed the retrospectivity of the law. Although the Constitutional Court stated that the Human Rights Court Law was unconstitutional, Soares' proposal remained rejected for the sake of human rights.

\section{The case of Former Members of Banned Political Party against the Election Law}

On February 24, 2004, 35 former members of banned political party (PKI) appealed to the Constitutional Court against the existence of the Article 60 (g) Law no. 12 (2003) on General Election which prohibited any ex-members of the banned Indonesian Communist Party-PKI and its mass organizations to be the member of Indonesian House of Representatives at all levels. Eight of nine Court judges approved the proposal for the sake of human rights.

\section{Social Discipline Concept}

\section{METHODOLOGY}

Conventional criminal sanctions focusing on 'offenders' is still considered as the only effective way in disciplining perpetrators and deterrent effect at this time. However, those sanctions are heavily criticized this is when a restorative justice theory is needed. To analyze how the implementation of the theory applied to human rights cases, it is necessary to understand the Social Discipline Window concept used.

The Social Discipline Window concept (Figure 1) shows how the assessment of society in the form of sanctions illustrated by combining two continuums of Control or influence on others and Support that sees how to nurture, encourage or assist others. Assessment of both continuums is calculated by the height of assessment. The control shows how social control an action or crime event, while the support shows how social support an action or event. The combination of the two continuums resulting approaches to punitive, permissive, neglectful, and restorative.

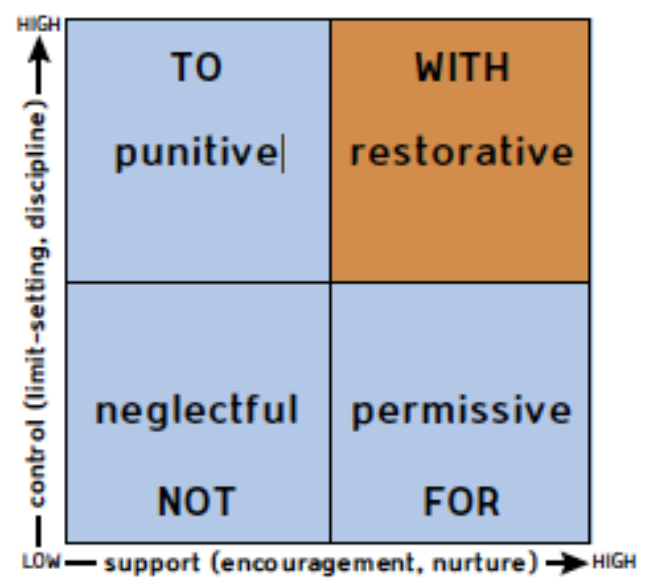

Fig 1. Social Discipline Window

Based on the figure, the position of high control and low support shows public approach to punish an action or crime. This punitive tends to stigmatize a person and label him negatively. This choice is also known as 'retributive' approach and by sanctioning the offender to 'recompense' the actions conducted. When the position of control is low and support is high, the community tend to do a permissive form on an existing crime. This approach is commonly known as 'rehabilitative' that tend to protect a person from the consequences of his own mistake. The low position of both control and support shows that the society tend to neglect and unconcerned about an existing action of crime. This neglectful form tends to be characterized by passive attitude of a society. Contrary, high position of both control and support justifying a restorative 
approach as the best reference as it disapproves the existence of a crime while emphasizing values of conducted action by the perpetrator.

The concept of Social Discipline also uses terms NOT, FOR, TO, and WITH describing approaches to offenders. In punitive approach, TO is used by a society to rebuke or punish offenders. In permissive approach, FOR is used by the society to excuse offenders for actions conducted. In neglectful approach, NOT is used to 'no' responses on offender actions, while in the restorative approach, the society will involve themselves 'WITH' offenders actively and invite all others to participate directly in healing and returning process of accountability.

\section{A. Social Impact in the Cases}

\section{DISCUSSION}

Social Discipline is a broad application concept using community as essential element to analyze actions and events (Wachtel, 2013). Therefore, it is important to know how the concept is applied by the Indonesian society in relation with above human rights cases. Hereby, the author is examining the validity of the concept in those human rights cases also as implied by McCold to openly test the application of conceptual restorative justice theory (McCold, \& Wachtel, 2003).

To those above-mentioned cases which also related to retrospective aspects, social perspective is used to justify whether a restorative justice model could be applied or not. The experiences are described in cases

- When law and political interests are met as in Masykur's case against the Terrorism Act (Samad, 2013), the Constitutional Court has to accomplish them in a way to protect human rights. Hence the definition of human rights in relation to terrorism amid foreign pressures for reliable terrorism trials were debated. To Social discipline, comments and perspective from the society on the case are matter.

Masykur, as well as most Bali bomb victims were member of Bali's community. Therefore, Masykur and other perpetrators court trials had attracted high social attentions. This high social attention caused by facts that Bali bombings were a terrifying incident causing resentment to both domestic and international communities, damaging international relations, tourism atmospheres, infrastructures and economic activities in the area (Acharya, 2006). Consequently, high social sentiments resulting public's desire to punish the perpetrators (Kirby, 2006).

How does the Social Discipline assess the status of Masykur as a convicted and victim? As a Balinese guide who worked to help a local tourist Imam Samudra for a rental residence and vehicle, Masykur was a victim of legal and political process. This consideration is based on; first, allegation to Masykur as the crime supporter was not proven within the court trials, however he still imposed for 3 years' imprisonment (Kirby, 2006). Second, Masykur had to bear unjust treatment as he was accused by a retroactive law against his constitutional rights [9]. Third, although the Constitutional Court has ruled that the law used to punished him was unconstitutional, he is determined to remain in prison for political interest (Kirby, 2006). These three reasons mark social judgments on Masykur to be permissive in social discipline concept.

As a matter of fact, the issue of foreign pressures demanded the implementation war on terror activities in Indonesia denotes difficulties in assessing social Discipline concept because the concept uses social perspectives that should not be disturbed by political interest in the form of social decisions.

- Overlapping interests of legal and politic shown in Masykur's was also seen in the case of Soares. As both interests were important in upholding human rights in society, debates on the definition of human rights in relation to gross human rights violation perceived. It is because the definition of gross human rights violation in East 
Timor tended to be understood differently by Indonesian lawyers and international observers. Also, formal definition of gross human rights violation is stated in the Rome Statute which is not yet ratified by Indonesia.

What was clear is that the society agreed that fair judgment should be made to any perpetrators committed crimes against humanity. As demands on past crime of human rights still voiced in Indonesia until now (www.amnesty.org, 2018), level of social punitive sentiment to those perpetrators of violence in East Timor was high. Though, seeing that Soares was 'the last man standing' civil defendant on the ad hoc Human rights Court for East Timor (The Jakarta Post, 2004), the position of Soares within the Constitutional Court was a victim of legal and political interest. Since Soares was prosecuted in the controversial ad hoc human rights trial, he mentioned that he would appeal to the next court as he was repeating claimed that he could not have prevented well-armed groups from a 'horizontal clash' as many orders came from Jakarta, not from his authority (Human Rights Watch). Also, he was prosecuted in the Constitutional court based on a retrospective law that against the constitution. Although the Constitutional Court has ruled that the law used to punished him was unconstitutional, his proposal was rejected because of a political aspect. It is obvious that Soares had to bear some of responsibilities demanded to Indonesia on the occurrence of crimes against humanity issue in East Timor through the Human Rights Court (Cohen, \& Lipscomb, 2012). As Soares was the only left perpetrator sentenced and all other military defendants were freed (The Jakarta Post, 2004), his punitive social discipline changed.

Both Masykur and Soares were victimized by a legal system affected by international suppressions. However, Soares case differs from the Masykur where the people tend to give permissive from the beginning. Community appraisal of Soares who was previously sanctioned for alleged humanitarian violence of punitive is more likely to be neglectful. Therefore, when the Constitutional Court rejected Soares's proposal of the retroactive law, the social consideration was not taken.

- The case of former members of PKI was also influenced by Indonesian socio-political considerations. It is because the court trial was filed by debates on the existence of Communism school and the organization in Indonesia. Past and recent developments of Indonesia were discussed within social and political perspectives. In one side, public judgments on PKI and its mass organizations were expressed as violence toward Indonesian people that abhorred. Indeed, there are still hatred on $\mathrm{PKI}$ and its activities to human rights (www.voanews.com, 2018) resulting a punitive assessment by the society. On the other side, society development during the reformation tended to blame Soeharto and the New Order including policies to ban the PKI were deemed incompatible with the development of human rights protection. This is then ex-members of PKI were considered victims of the New order regime to be permissive appraised.

As a matter of fact, arguments on the favor of ex-members were actually expressed in line with social intention to establish high appraisal on human rights enforcement that was not accommodated during the New Order regime. This appraisal was not intended to support the existence of PKI and Communism school in Indonesia as shown in current development of society when they realize that the appraisal to the ex-members of $\mathrm{PKI}$ is wrong. It is because worries on the rise of Communism school threatening the unity of Indonesia has emerged within social concerns (Allard \& $\mathrm{Da}$ Costa, 2017). This concern is visible as spirit euphoria within reformation did not shown meaning revoke the Provisional People's Consultative Assembly and the forerunner of the People's Consultative Assembly -MPRS Decree No. XXY/1966 on the PKI Banning. To social discipline concept, if only rights of those ex-members of 
PKI to be the member of House of representative was sustained by revocation of the MPRS Decree, the concept of restorative justice would meet.

B. Social Discipline in Legal Politic of Human Rights

The concept of Social discipline shows that every one who has authority within in the community has a choice to maintain the social discipline. The decision of the Constitutional Court and Indonesian government within the case of Masykur was an authority to attempt a restorative model in accommodating interests of law, politics, foreign pressures, and the protection of victims rights. When the Minister of Justice and the Chief Justice of the Constitutional Court, immediately right after the decision of Maskur's, announced that the decision was progressive, they knew that the act would not ethically normal in legal perspective, proven by some lawyers critics (Kirby, 2006), but effectively implementing political support on war on terrorism trend. If only social support on the decision show high level of support continuum, the action of the Constitutional Court and the Government would form a restorative achievement as in social discipline concept.

As McCold points out that 'high' and 'low' on control and support continuums are expressed whether clear standard of behavior, aids and active attentions to the welfare of the community are exist or not, Masykur proposal on the retrospectivity of the Law No. 16 (2003) on Bali Bomb was legally accepted by the Constitutional Court in concurrence with high control continuum as it was based on a clear rule of law. However, the announcement of the Minister of Justice and the head of the Constitutional Court had initiated restorative approach on the favor of Masykur could not achieved. By this, the Court's decision was inconsistency with the constitutional human rights protection as it was prioritizing political interest. To this, social support is low.

Although the Constitutional Court's decision was not tranquilly taken, it was seemingly a right step amid Indonesian condition in human rights as stated by the Hon. Justice Michael Kirby who mentioned that Masykur case was a test to general human rights protection (Kirby, 2006). Indeed, the annulment of the Bali Bomb Terrorism Law by the Constitutional Court became a good experience for the government to avoid hasty enforcement and ignoring social involvement in it (Butt, 2008).

Although it is agreed that Bali bomb tragedies needed quick responses from the government, but to a restorative social discipline concept, any regulation promulgation should involve social participation. Another verification that the law was not socially oriented shown in the Art. 64 stating 'legislation can be applied retroactively and regulates past events of 'certain criminal cases' determined by law or government regulation. By this, it is also 'alarming' potential abuse of power (Stockmann, 2007).

To Soares case, Constitutional Court and the government also show punitive approach as Soares' proposal was rejected although the Art. 43 of Law No. 26 (2000) of the Human Rights Court used to sentenced him was proven retrospective. Different to Masykur's, the rejection of Soares' appeal was socially more acceptable in high control of punitive approach as Soares was blamed with a commonly abhorred crime against humanity. Indeed, as the decision was contrary to the constitutional human rights protection, the Court charge signaled non-independent political behavior (iafor.org, 2016) to adapt critics of the ad hoc court accountability. It is because the decision was negatively taken although in favor of international sights who repeatedly criticized Indonesian ad hoc human rights trials. To Soares trial, the ad hoc court was criticized because the court had freed all suspected militaries leaving Soares as the only civilian sentenced (The Jakarta Post, 2004). To Social Discipline Concept, as Masykur and Soares cases were about violation to humanity and impacted widely on society, McCold agreed that weak behavioral standard of Indonesia human rights protection (Indrayana, 2008) by the law enforcement characterizing low social control resulting low emotional social support. 
On the other hand, the case of former members of PKI shows a vague protection on Indonesian human rights. Factually, in Soeharto and New Order regime, all forms of PKI oriented activities and its mass organizations were banned (Van Bruinessen, 2002) and massive anti-PKI activities ranging from the highest to the lowest levels of the government were launched. This was including 'screening' of social involvement in all government and private institutions. To Social Discipline concept, the announcement of MPRS Decree on the banning of PKI was a government retributive action in a high control to punitively approach caused low social support to PKI. This was enhanced by massive and continually propagandas on PKI's cruelties towards Indonesian. By this, the meaning of human rights protection on the favor of PKI was not defined.

Then, reformation euphoria in mid-1998 forcedly echoing anti-New Order and refusal to policies on human rights produced by the regime. New Order policies on human rights were voiced to be re-uphold, especially those in connection with violence allegedly conducted by the New Order regime. To this strong social environment supported by ulama' (Ichwan, 2005), the Constitutional Court decided to accept the proposal of the former members of PKI for the sake of human rights resolution, showing. Hence, the Court and government decision had to adapt and squeezed by high social control and support shown in the Social Discipline concept. To the concept, this is a restorative form of justice.

However, recent social development shows reluctances to accept PKI or any Communism-related activities (www.telesurtv.net, 2016; www.independent.co.uk, 2017) under the issue of united Indonesia as a State and identity. The reluctance of the society to fully accept the ex-members of PKI and Communism school under the name of human rights was actually indicated within reformation euphoria as voices to revoke ban in MPRS Decree were not demanded. Socially, the society of Indonesia still put angers of the vengeance to Communism activities traumatized by their activities in the past. By this, high social discipline concept on control continuum is not supported by social support continuum removing ex members of PKI to be opted in a restorative justice perspective.

\section{CONCLUSION}

As restorative justice-oriented application and human rights protection are imperatively needed in developing progressive legal performance of Indonesia, the people should know how those restorative concepts and human rights policies performed by the government. Therefore, the involvement of social perspective as in Social Discipline concept is worth to be verified through cases of Indonesian Human Rights.

As explained above, a minor example of Indonesian human rights cases have shown that law and political interests in human rights were still coincided in their submissions to the society. To this matter, differences on the approaches and policies in the issue are still open to be discussed. In connecting those approaches and polices, the aspect of medias has played important role in forming social opinion. The power of media technology in altering or modifying in-out social information then should necessarily be considered within the concept of the social discipline.

\section{REFERENCE}

Acharya, A. (2006). The Bali Bombings: Impact on Indonesia and Southeast Asia. Center for Eurasian Policy Occasional Research Paper, Series II (Islamism in Southeast Asia), (2), 1-5.

Braithwaite, J. (2002). Restorative justice \& responsive regulation. Oxford University Press on Demand.

Butt, S. (2008). Anti-terrorism law and criminal process in Indonesia. University of Melbourne. Centre for Islamic Law and Society. ARC Federation Fellowship. 
Cohen, D., \& Lipscomb, L. A. (2012). When more may be less: Transitional justice in East Timor. Nomos, 51, 257-315.

Ichwan, M. N. (2005). Ulama, State and Politics: Majelis Ulama Indonesia After Suharto. Islamic L. \& Soc'y, 12, 45.

Indrayana, D. (2008). Indonesian Constitutional Reform, 1999-2002: An Evaluation of Constitution-Making in Transition. Penerbit Buku Kompas.

Karp, D. R., \& Breslin, B. (2001). Restorative justice in school communities. Youth \& Society, 33(2), 249-272.

Keputusan Mahkamah Konstitusi 013/PUU-I/2003, no. 02. 2003.

Kirby, M. (2006). Judicial Review in a Time Of Terrorism-Business as Usual. South African Journal on Human Rights, 22(1), 21-46.

McCold, P., \& Wachtel, T. (2003, August). In pursuit of paradigm: A theory of restorative justice. In Paper presented at the XIII World Congress of Criminology (Vol. 10, p. 15).

S. Wright, "US knew about 1960s mass killings of communists in Indonesia, declassified documents reveal The In, https://www.independent.co.uk/news/world/asia/indonesia-anti-communistmassacres-1960s-us-knew-cia-desclassifed-embassy-files-jakartaa8006186.html" Wednesday 18 October 2017 08:00, 2017.

Samad, I.D. (2013). Retrospectivity and Human Rights in Indonesia, Indones. J. Int'l Law, vol. 10, no. 2, p. 340.

Stockmann, P. (2007). The New Indonesian Constitutional Court. A study into its beginnings and first years of work. "Jakarta, Hanns Seidel Stiftung/Watch Indonesia.

T. Allard \& A. B. Da Costa, "'Red Scare' puts pressure on Indonesian president | Reuters." https://www.reuters.com/article/us-indonesia-politics-military/red-scareputs-pressure-on-indonesian-president-idUSKCN1C21AQ [Accessed: 25-Jul2018].

Van Bruinessen, M. (2002). Genealogies of Islamic radicalism in post-Suharto Indonesia. South East Asia Research, 10(2), 117-154.

Wachtel, T. (2013). Defining restorative. International Institute for Restorative Practices, 1-2.

Y. and F. D. U. Fointuna, "Ex-governor Abilio Soares escapes jail for now," The Jakarta Post, 2004.

Zulfa, E. A. (2011). Restorative Justice in Indonesia: Traditional Value. Indon. L. Rev., 1, 33.

"Communist' Still a Dirty Word in Indonesia." https://www.voanews.com/a/lien-hoangcommunist-still-dirty-word-in-indonesia/1838804.html [Accessed: 25-Jul-2018].

"Guardian, Bali bomber sentenced to death," 2003.

"Indonesia Verdict Confirms Justice Elusive for East Timor Crimes | Human Rights Watch."

"Indonesia: Millions of victims and families still abandoned 50 years after mass killings | Amnesty International." [Online]. Available: https://www.amnesty.org/en/pressreleases/2015/09/indonesia-millions-of-victims-and-families-still-abandoned-50years-after-mass-killings/. [Accessed: 25-Jul-2018].

"Indonesia's 51-Year-Old Ban on Communism to Stay in Place | News | teleSUR English," 25 August 2016, 2016. [Online]. Available: https://www.telesurtv.net/english/news/Indonesias-51-Year-Old-Ban-onCommunism-to-Stay-in-Place-20160825-0002.html.

"Ineffectiveness of Enforcement of the Constitutional Court's Decision in Indonesia," 2016. https://papers.iafor.org/submission32429/ [Accessed: 25-Jul-2018]. 